\title{
Newman, Catholicity, and the Church Today: On the Development of Christian Principles through Dialogue with the World
}

\author{
Christopher Cimorelli
}

check for updates

Citation: Cimorelli, Christopher. 2021. Newman, Catholicity, and the Church Today: On the Development of Christian Principles through Dialogue with the World. Religions 12 : 507. https://doi.org/10.3390/ rel12070507

Academic Editor: Ilia Delio

Received: 21 June 2021

Accepted: 2 July 2021

Published: 7 July 2021

Publisher's Note: MDPI stays neutra with regard to jurisdictional claims in published maps and institutional affiliations.

Copyright: (C) 2021 by the author. Licensee MDPI, Basel, Switzerland. This article is an open access article distributed under the terms and conditions of the Creative Commons Attribution (CC BY) license (https:// creativecommons.org/licenses/by/ $4.0 /)$
National Institute for Newman Studies Pittsburgh, Pittsburgh, PA 15213, USA; ccimorelli@ninsdu.org

\begin{abstract}
This article explores the following question: Given the Roman Catholic Church's presentday teaching on catholicity, how can St. John Henry Newman's historically conscious, imaginative view of catholicity assist Catholic Christians today in understanding the concept faithfully, but in a manner 'open' to its potential development in an age of shifting metaphysics? After (1) an introduction to the topic and challenges to the notion of catholicity today, this article then (2) analyzes the present-day view of catholicity as a mark of the church according to the 'Catechism of the Catholic Church', noting areas of development as well as limitations. The article then (3) investigates Newman's understanding of catholicity within his sacramental and imaginative worldview. Newman's understanding of the development of principles and doctrines is particularly relevant for a consideration today of how the church's view of catholicity might authentically develop from a dialogue between religion and science. The article then (4) synthesizes results in a concluding section that indicates how the fruits of the preceding analysis could be realized through eco-theological dialogue.
\end{abstract}

Keywords: catholicity; wholeness; St. John Henry Newman; evolution; ecology; ecotheology; science and religion; faith and reason; doctrinal development; principles

\section{Introduction}

The idea and attribute of 'catholicity' is essential to the self-understanding of Christianity, and particularly for the Roman Catholic communion given not only its creedal beliefs (CCC 1993, no. 176ff), but also its claims of being the church in which Christ's presence subsists fully, providing the means of salvation sacramentally (LG 1964, nos. 8, 14; UR 1964, nos. 3-4). While the word 'catholic' (katholikos) is often translated as 'universal', a better translation from an etymological perspective is "throughout the whole" (Finucane 2011, p. 115; cf. Delio 2015, p. xi), even implying a spreading throughout the whole. In a world with increased historical consciousness and perhaps an over-consciousness of plurality and difference, the notion of catholicity-or the quality of being catholic-is not always clear. Moreover, the idea of catholicity is situated in a metaphysical and sacramental view of reality. Such a view has experienced ongoing shifts throughout Christian history, for example in the passage from more participatory frameworks to more secular and scientific ones. In the present context, developments in fields such as biology (the emergence of life via open evolutionary processes) and quantum physics (relativity within the space-time continuum) also bear upon ideas of wholeness and views of ultimate reality.

Christians who endeavor to understand and pass along their faith are thus challenged to reflect on this concept in accordance with the "signs of the times" (GS 1965, no. 4; Matt. 16:3 NABRE) and in a manner that both respects the church's long held but developing beliefs, and factors in the context and horizons of meaning in which believers find themselves. In this article, I will explore how John Henry Newman's effort to understand catholicity according to a principle of sacramentality is especially useful-at a foundational level-for Catholic Christians today. The particular question driving this investigation is the following: given the church's present-day teaching on catholicity, how can Newman's 
historically conscious, imaginative view of catholicity assist Catholic Christians today in understanding the concept faithfully, but in a manner 'open' to its potential development in an age of shifting metaphysics? Regarding the notion of catholicity, Newman is a critically important figure, given his role in articulating a theory upholding the development of doctrine for the sake of continuity that would largely influence the church's understanding of tradition-development at Vatican II (see Parker and Shea 2015; Ker 2014, pp. 40-71; Nichols 1990). In fact, Newman's 'An Essay on the Development of Christian Doctrine' (Newman [1878] 1909, [1845] 2010) specifically analyzed catholicity and how it develops and may be understood by the faithful. His arguments might be surprising to many, given the productive tension they maintain; namely, the need for a living teaching authority to judge what is according to the whole to secure revelation, on the one hand, and a genuine openness to critical dialogue and truth 'extra ecclesiam', wherever it may be found, on the other.

Concretely, the article will proceed in three sections beyond this initial one. Section 2 will explore the Catholic Church's prevailing view of catholicity as primarily found in the 'Catechism of the Catholic Church' (CCC). The CCC offers a definition of the term and two primary dimensions to it: namely, the presence of Christ in the church(es)' spread throughout the world, and the missional or evangelical nature of the church. In addition, this section will highlight paragraphs from the Second Vatican Council document, 'Gaudium et Spes', that seem particularly relevant for the church's understanding of catholicity, but which are not cited in the CCC. Section 3 will present and analyze Newman's understanding of catholicity and the sacramental principle as developed in his 'Essay on Development'. While this work is not the only locus where one can find his reflections on catholicity, it is nevertheless one of the primary places in which he reflects on the concept at length, while also treating the development of the 'Christian Idea' and its principles. Particular attention will be paid to the manner in which Newman's view calls for engagement with the broader world and scientific disciplines with potentially normative consequences. The result supports the productive tension noted above. The final, concluding section (Section 4) will briefly consider how the engagement today of ecotheologians with scientific disciplines may yield developments in the church's understanding of catholicity according to the view developed in the preceding sections.

\section{The Catholic Church's View of Catholicity}

While treatments of the Catholic Church's view of 'catholicity' are many, an analysis of this concept as primarily found in the CCC is helpful given how this work, sanctioned from an institutional perspective, summarizes the Catholic view in the light of recent conciliar teachings, scripture, and tradition. The CCC treats the notion of 'catholic(ity)' quite often, but a more focused treatment is found in "Article 9, 'I believe in the Holy Catholic Church,'" Par. 3 ("The church is one, holy, catholic, and apostolic"). Section III (nos. 830-56) specifically treats the mark of the church, catholic. A review of this section will help to delineate questions about the possible development of the notion of catholicity.

According to the CCC no. 830, the "word 'catholic' means universal, in the sense of 'according to the totality' or 'in keeping with the whole.'" This more etymologically faithful rendering is then clarified in terms of the church. When the church refers to itself as 'catholic', it is meant in two senses: because (1) "Christ is present in her" (CCC 1993, no. 830) and (2) "because [it] has been sent out by Christ on a mission to the whole of the human race" (CCC 1993, no. 831). Section III proceeds to delineate how each particular church is 'catholic', how full 'catholicity' is "through communion with one of them, the Church of Rome" (CCC 1993, no. 834), and that the universal church is not reducible to the sum of the individual churches (CCC 1993, no. 835).

\subsection{Catholicity and Christ's Presence}

In terms of membership or belonging to the Catholic Church, several degrees are indicated. First, there "are those, possessing the Spirit of Christ, [who] accept all the means 
of salvation given to the Church together with her entire organization, and who-by the bonds constituted by the profession of faith, the sacraments, ecclesiastical government, and communion, are joined in the visible structure of the Church of Christ, who rules her through the Supreme Pontiff and the bishops" (CCC 1993, no. 837). Here, the CCC indicates the entirety of the visible and invisible catholic communion, from its sacraments to institutional structure and hierarchy. Members of this communion, presumably active and in good standing, participate fully in the church, and this points to the varying levels of ecclesial participation applicable to other persons. In this vein, and second, non-Catholic Christians do enjoy an "imperfect ... communion with the Catholic Church" (CCC 1993, no. 838), given the lack of participating in the full means of salvation noted above (LG 1964, nos. 8, 14; UR 1964, nos. 3-4). Third, in a lengthy subsection, the CCC treats the relationship of non-Christians with the church. Special attention is given to the Jewish people, "the first to hear the Word of God"' and to whom "'belong the sonship, the glory, the covenants, the giving of the law, the worship, the promises...the patriarchs ... and ... according to the flesh ... the Christ'" (CCC 1993, no. 839). Muslims are also set apart for professing "to hold to the faith of Abraham, and together with us they adore the one, merciful God" (CCC 1993, no. 841). The CCC does attend to other, non-Abrahamic religions and people of good will, following the content of the Vatican II declaration 'Nostra Aetate' (NA 1965). The bond between non-Christians and the Catholic Church is "the common origin and end of the human race" (CCC 1993, no. 842), and the truth and goodness contained in such religions are considered "'a preparation for the Gospel and given by him who enlightens all men [sic] that they may at length have life'" (CCC 1993, no. 843; citing LG 1964, no. 16).

The Catholic Church is considered the locus where God has willed the reunification of a fractured humanity "led astray" by sin and evil (CCC 1993, no. 845). With these classifications established, the subsection finally comments on the traditional formula, "extra ecclesiam nulla salus" ("outside of the church there is no salvation"), clarifying positively that all salvation flows from Christ-the head of the church-through the church which is Christ's body in the world (CCC 1993, nos. 846-848). In order to square this with what has just come before, no. 847 cites 'Lumen Gentium' 16: “Those who, through no fault of their own, do not know the Gospel of Christ or his Church, but who nevertheless seek God with a sincere heart, and, moved by grace, try in their actions to do his will as they know it through the dictates of their conscience-those too may achieve eternal salvation" (in CCC 1993). If one lives sincerely and by conscience, seeking God even without formal participation in Christianity, then salvation is possible. In addition, there is the implication that, if one truly understood the economy of salvation established by God and the church's role in that economy - throughout the world - then one would not refuse to be a part of it (see LG 1964, no. 14). A number of theologians have reflected on the developments in church teaching engendered by the Second Vatican Council and documents such as 'Lumen Gentium' and 'Nostra Aetate'. For example, Edward Schillebeeckx reflected on this very dilemma about salvation outside of the formal boundaries of the Catholic Church, noting that this traditional formula, in hindsight, is better understood as saying something about the church rather than representing a definitive judgment of all persons outside of the church (Schillebeeckx 2014b, pp. 97-101). This led him to ponder the notion that a larger notion of the church was needed, and to offer the following take on the church and world: "extra mundum nulla salus" ("outside of the world there is no salvation") (Schillebeeckx 2014a, p. 12).

\subsection{Catholicity and Mission in the World}

The remaining content of Section III (CCC 1993, nos. 849-56) treats the second element constituting the church's catholicity: namely, its being sent out into the whole worldmission is thus a requirement of the church intended to be "the universal sacrament of salvation'" (LG 1964, no. 48), striving "to preach the Gospel to all [people]" (CCC 1993, no. 849). The church has been commissioned and sent out "to make disciples of all nations, baptizing them in the name of the Father and of the Son and of the Holy Spirit" (ibid.; 
citing Matt. 28:19). The source of this mission in the world is the very being of God, who is trinitarian love poured out to humanity, inviting persons to share in this relational, charitable love and to be transformed by it. This sharing represents not only the true goal or telos of all people as willed by God, but also the desire for truth that is part of the human journey and experience (see DH 1965, no. 2). The church has been entrusted to bear the truth and share it the world over. As indicated in John's gospel and as recounted from Pentecost forward, the Holy Spirit assists the church in this mission and ultimately pilgrim journey of faith (see John 16:13; Acts 1:8ff). The church must take "the 'way of penance and renewal'" (CCC 1993, no. 853; citing LG 1964, no. 8) given the tension between the gospel proclaimed "'and the human weakness of those to whom the Gospel has been entrusted"' (CCC 1993, no. 853; citing GS 1965, no. 43), so that saving truth can indeed be communicated. This communication is aimed especially toward those "who do not yet believe in Christ," and a "process of inculturation" is necessary for "the Gospel to take flesh in each people's culture" (CCC 1993, no. 854; cf. Schreiter 2012; Doyle 2012). Patience is a requirement, because "it is only by degrees that [the Church] touches and penetrates them and so receives them into a fullness which is Catholic'" (ibid.; citing AG 1965, no. 6). Recalling the bond shared by the church with non-Christian religions around the world —-that is, a common origin and end —it is significant that the church here is described not just as a leaven to the world, but also as "'the soul of human society in its renewal by Christ and transformation into the family of God"" (CCC 1993, no. 854; citing GS 1965, no. 40).

This latter point is quite intriguing given what it implies about the church's presence in/to the world. A soul is present to the body, to which it gives life and form. If all of human society is called to have the church as its soul, then the church cannot, it would seem, retreat defensively from fallen society and the world, but rather must engage. Indeed, the CCC continues, saying that this missionary task with its incremental gains realized in particular societies, "implies a respectful dialogue with those who do not yet accept the Gospel. Believers can profit from this dialogue (CCC 1993, no. 856) given "'those elements of truth and grace which are found among peoples, and which are, as it were, a secret presence of God'" (ibid.; citing AG 1965, no. 9). As presented in this section of the CCC, the church's status as soul of human society might be conditional upon the acceptance of Christ by specific societies and the renewal that occurs with inculturation. It is not especially clear in this context what benefits are received by believers from respectful dialogue with non-Christians, or whether the church itself receives benefits from this dialogue (cf. Benedict XVI 2013, par. 20ff).

\subsection{Catholicity and Benefits to the Church Even from Opposition}

It is striking that, in all of Article 9.3 treating the four marks of the church-and particularly Section III on catholicity-the CCC does not reference 'Gaudium et Spes' nos. 44-45. The CCC, Par. 3, does make use of many Vatican II documents, including 'Ad Gentes', 'Lumen Gentium', 'Nostra Aetate', and 'Gaudium et Spes', but nos. 44-45 of 'Gaudium et Spes' specifically emphasize the benefit that accrues to the church as it engages the world in fulfilling its task of evangelization. This benefit is not limited to the latent contributions of converted non-Christian communities, but rather includes science and general human progress.

"The experience of past ages, the progress of the sciences, and the treasures hidden in the various forms of human culture, by all of which the nature of man himself [sic] is more clearly revealed and new roads to truth are opened, these profit the Church, too. For, from the beginning of her history she has learned to express the message of Christ with the help of the ideas and terminology of various philosophers, and ... has tried to clarify it with their wisdom, too. Her purpose has been to adapt the Gospel to the grasp of all as well as to the needs of the learned, insofar as such was appropriate. Indeed this accommodated 
preaching of the revealed word ought to remain the law of all evangelization."

(GS 1965, no. 44)

The engagement with "various forms of human culture" has profited the church by helping it "express the message of Christ" in an appropriate way in diverse contexts. "With the help of the Holy Spirit, it is the task of the entire People of God ... to hear, distinguish and interpret the many voices of our age, and to judge them in the light of the divine word, so that revealed truth can always be more deeply penetrated, better understood and set forth to greater advantage" (ibid.). This engagement, assisted by the Holy Spirit, is considered part of the "law of evangelization" and is thus a critical element of the church's catholicity in terms of mission in and to the world.

'Gaudium et Spes' goes even further than this, clarifying the benefit that accrues to the church even from its opponents, something that is possible given the church's structure and mission in the world. "Since the Church has a visible and social structure as a sign of her unity in Christ, she can and ought to be enriched by the development of human social life, not that there is any lack in the constitution given her by Christ, but that she can understand it more penetratingly, express it better, and adjust it more successfully to our times" (ibid.). The church is a visible and social structure united by Christ but also embedded within reality, on which it depends for realizing its mission. 'Gaudium et Spes' notes that "whatever promotes the human community" at varying levels "is contributing greatly to the Church as well", regardless of confessional affiliation (ibid.). "Indeed, the Church admits that she has greatly profited and still profits from the antagonism of those who oppose or who persecute her" (ibid.). The church, which also helps the world, receives benefits while maintaining "a single intention": "that God's kingdom may come, and that the salvation of the whole human race may come to pass" (GS 1965, no. 45). The church's benefits to the world stem from the fact of its being "the universal sacrament of salvation," and it must realize its tasks in diverse ways, taking advantage of whatever can support its mission in the world.

Thus far, the above portrait has shown that the Roman Catholic understanding of the church's catholicity as realized in the world has developed significantly, especially from Vatican II forward. Developments are visible in the church's awareness of truth and contributions from other persons, communities, and disciplines regardless of denominational affiliation. Such awareness and the proceedings of the Second Vatican Council have even engendered a "plurality of theologies" that "is undoubtedly necessary and justified" because the church, in the light of its catholicity, "strives to proclaim the one Gospel to people everywhere, in all kinds of circumstances" (International Theological Commission 2011, no. 77). While the church must forever work "to make disciples of all nations," it has also (re)discovered the goodness of creation and presence of God indicated throughout it. In addition, even as the church preaches God's kingdom and prophetically resists that which undermines the dignity of life, it also potentially benefits from engagement even with those who in set terms oppose it, provided any such benefits are utilized in carrying out its mission of evangelization (see Paul VI 1975). This latter point, especially as found in 'Gaudium et Spes' (pp. 44-45), is important to factor into the discussion of catholicity as found in the CCC, Article 9.3.III, which does not specify the benefits that believers (or the church) receive from preaching the gospel to non-Christian communities. The focus instead is on distilling "the elements of truth and grace" in such communities, perhaps only possible after a process of inculturation has taken place.

But what about the church's fundamental understanding of catholicity as a principle and marker of its life both unified in Christ who is present sacramentally, on the one hand, and as God's people sent into the world, on the other? While these two dimensions of catholicity are abiding, is it possible that the church's understanding of catholicity itself may authentically develop given that ongoing engagement with the world is a fundamental part of its divine mission? Words such as "universal" and ideas regarding what is true "according to the whole" have been problematized in the present context by the rise of historical consciousness, awareness of diversity/difference, and scientific breakthroughs 
such as the theory of evolution. Section 3 immediately below will utilize the theology of John Henry Newman to engage the questions broached above. The CCC and 'Gaudium et Spes' indicate that such engagement and possible development could very well assist the church in fulfilling its mission.

\section{John Henry Newman on Catholicity and Its Development}

When writing his 'Essay on Development' in 1845, John Henry Newman was not merely engaging in second-order theological reflection. Rather, he sought to address the emerging crisis of historical consciousness that revealed stark differences between ancient and present-day Christianity, threatening any sense of genuine continuity. He thus developed "an hypothesis to account for a difficulty" (Newman [1878] 1909, p. 30) so that opponents of Christian truth claims would not go unchallenged; in fact, anyone who disagreed would, presumably, need to provide a better explanation than he did. "[A]n argument is needed, unless Christianity is to abandon the province of argument" (ibid., p. 31). This crisis, moreover, was personal in that Newman's own ecclesial membership was on the line, as he struggled to discover the church that could exist amid and accommodate the sweep of history while safeguarding God's revelation (see Newman [1907] 2004, pp. 130-31). His work in the 'Essay on Development' thus facilitated a deep engagement with the way that ideas, concepts, and even principles might change or develop over time while remaining in continuity with their origins. His resulting theory of doctrinal development balanced a strong commitment to the teaching authority of the church and the necessary fact of development. Newman's theory has proved influential for Roman Catholic Christianity, since its reception played a significant part in the way that tradition development was explicated at Vatican II, especially in the dogmatic constitution, 'Dei Verbum' (DV 1965, no. 8). This section will analyze Newman's understanding of catholicity within the essay, both as an abiding mark of the church, but also as a principle that develops in the understanding of believers. Indeed, a critical evaluation of his arguments reveals that they pair well with shifts in worldview precipitated by scientific breakthroughs such as evolution.

\subsection{The Study of History and Catholicity in Newman's Essay}

Given that catholicity is in many respects the subject of Newman's entire 'Essay on Development', it is prudent here to present an overview of Newman's argumentation regarding the concept and how it fits within his sacramental worldview. Doing so will raise the issue of Newman's understanding of principles, doctrines, and how they develop.

Prior to the 'Essay on Development', Newman sought to justify the view that the Church of England was the authentic branch of Christianity that avoided the errors of both Protestantism (sacrificing early church tradition) and Roman Catholicism (corruption of doctrine). This effort resulted in the work 'Lectures on the Prophetical Office of the Church' (1837), later published as 'The Via Media of the Anglican Church' (vols. 1 and 2, 1877 and 1883). In this work, Newman held that the primitive 'Church Catholic' exhibited the principles of catholicity and apostolicity: that is, it was unified in what was taught throughout the whole in accordance with and faithful to the church as founded by the apostles and later harmonized by the church fathers. "Catholicity, Antiquity, and consent of Fathers, is the proper evidence of the fidelity or Apostolicity of a professed Tradition" (Newman [1877] 1901, p. 51) As time moved forward, however, the church was fragmented, forever undermining its catholicity. Newman's lectures were meant to show that, in the absence of true catholicity, it was imperative for the present branch of Christianity to maintain apostolicity, with current doctrine grounded in scripture and the tradition of the early church prior to its fracturing and corruption (ibid., pp. 1-25). Newman was never really satisfied with the results of this work, feeling that the ecclesiology he developed was more abstract than realized (see Newman [1865] 1908, pp. 68-72, at 72). In the time after this 1837 work and prior to his 'Essay on Development', he engaged in historical studies 
of the early church period, particularly heresies, and was motivated to formulate a new theory that could better account for the historical evidence (Cimorelli 2017).

Newman was heavily influenced by his study of the Donatist and Monophysite controversies (Newman [1865] 1908, pp. 92-146). The Donatists were "the followers, in the fifth-century African Church of Donatus, "who formed a schismatical sect ... claiming to be the True Church, which was strict about matters such as sin and martyrdom. They were doctrinally orthodox" (Thomas 1991, p. xii). Donatists maintained that "the Church of the saints must be holy ... and that sacraments conferred by" unworthy church leaders and priests-including those who had betrayed the faith by handing over sacred texts and other items ('traditores') were invalid (Cross and Livingstone 1997, s.v. "Donatism," p. 500). Newman was dismayed to find that this rigorous ancient sect exhibited orthodoxy in terms of continuity with received tradition, as well as commitment to holiness in sacramental efficacy, but were nevertheless judged as being in error by the wider, catholic church St. Augustine of Hippo wrote against the Donatists, emphasizing that "the unworthiness of the minister did not affect the validity of sacraments, since ... their true minister was Christ" (ibid.). Augustine's arguments on catholicity and judgment were particularly impactful for Newman, who recollected years later the power of Augustine's famous dictum, 'securus judicat orbis terrarum' ("the whole world judges correctly"), which echoed in his mind, shattering any remaining confidence in his theory of the via media of the Anglican communion (Newman [1865] 1908, pp. 116-17). The history of the Donatists exemplified to him that the simpler principle of catholicity had been utilized to maintain the unity of the church, even judging matters of antiquity. Newman began to realize that, just as the early church had needed to interpret scripture and make authoritative judgments in response to new questions and challenges, so too did the later church when history demanded it.

Newman's dive into Monophysitism and the Council of Chalcedon (451 CE) only reinforced his shifting perspective. Newman's historical studies showed that, well into the fifth century, the church was displaying fissures and discord between its Western and Eastern manifestations on the critical question of Christ's constitution (Newman [1878] 1909, p. 273ff). Eastern authorities at the Second Council of Ephesus in 449 CE had mistreated and excluded the representatives of Pope Leo and the Western church (ibid., pp. 299-300), and despite this council's appearance of catholicity in terms of general attendance and decrees, the violation of the more implicit prerogatives of the Western church, and especially the See of Peter, facilitated the emergence, concretization, and development of the principle of catholicity—specifically the sub-principle of papal primacy-in Newman's eyes (ibid., pp. 148-65, 299ff). The result, after years of discord and harsh rhetoric, was the Council of Chalcedon, at which the Christology of Pope Leo was read before those gathered and influenced the final decrees about Christ's constitution of 'one person in two natures.' According to Newman, these events manifested the latent principle of papal primacy, but only when the controversies and conditions of history demanded it, and this all proved normative for catholic Christianity moving forward.

Ultimately, the Donatist and Monophysite controversies proved to Newman that the principle of catholicity did and could continue to decide questions bearing upon the church's antiquity, and that one of the most important councils of Christianity involved the manifestation of the prerogatives of Rome and its bishop, the pope. Newman's study of the past was thus part of the process that led him to see his own communion as in schism from the true branch of Christianity, Rome, despite any doctrinal extravagance that Rome displayed. Moreover, just as the early church needed a living teaching authority to judge matters of faith, so too did the later church, and Newman came to believe that the Roman Catholic communion possessed this very 'organ' that could prevent the ultimate corruption of the faith and thus secure God's revelation with the help of the Holy Spirit (see ibid., p. 90). Given Newman's ecclesiological concerns at this time and these conclusions, he displayed what Ryan Marr has called "moderate ultramontanism" (Marr 2018, pp. 1-47). This is a fair assessment, and Newman's ecclesiology would certainly see more balance as he 
engaged Catholic life and thought in the second half of the nineteenth century (Marr 2018; Merrigan 1991, pp. 142-48). However, Newman's theory, with its intense focus on the nature of Christianity as a historical, developing reality, as well as the normativity of history in terms of how the church manifests when facing challenges, ultimately yields a productive tension. Namely, continuity involves change, and development often involves a faithful 'assimilation' of that which Christians encounter in the wider world, and which will help them articulate and perpetuate their beliefs (Newman [1878] 1909, p. 355ff). ${ }^{1}$

\subsection{Principles, Doctrines, and Their Development}

One of the reasons for this productive tension is Newman's understanding of principles and doctrines, and how this relates specifically to catholicity. In the 'Essay on Development', Newman argues that doctrines (i.e., Christian teachings) are expressions of deeper, sometimes unexpressed principles. "Principles are abstract and general; doctrines develop [sic], and principles at first sight do not; doctrines grow and are enlarged, principles are permanent" (ibid., p. 178 (emphasis mine)). In fact, doctrines and further developments of doctrine are understood as manifestations of the operation of principles in the church's life. Such principles have been with Christianity from the very beginning of its life, but become manifest and are understood more clearly as time passes, and particularly when they are under threat, as Newman found in the historical studies noted above. This view is indicative, generally speaking, of Newman's romanticism and imaginative perspective (see (Cimorelli 2017, pp. 38-50 (esp. 45ff)); Pereiro 2008; Prickett 1976), which holds that Christ impressed upon his first followers the idea of Christianity (including its fundamental principles) that would abide and manifest throughout time, developing in the course of history (Newman [1878] 1909, p. 33ff). For example, "The principle of dogma [involves] supernatural truths irrevocably committed to human language, imperfect because it is human, but definitive and necessary because given from above" (ibid., p. 325). Generally speaking, then, the church's doctrinal utterances-including some considered to be binding dogmas of the faith-are illustrations of this more fundamental dogmatic principle, which is made possible by God's activity or engagement with history. ${ }^{2}$ In the life of the church, the action of the Holy Spirit thus enables the use of human language to treat and preserve truths that transcend it and, in fact, are beyond the human mind to grasp fully (see Newman [1835] 1908, p. 227). Perhaps not surprisingly, this dogmatic principle was at play in the doctrinal debates of the early church that were referenced above and critical for an understanding of the term 'catholic' for Newman.

Regarding catholicity, Newman refers to it variously: as an attribute and principle of the church, as well as a function of a deeper sacramental principle. In a section treating the church of the fourth century and its discordant factions, he states simply of this attribute of catholicity: "The Church is everywhere, but it is one" (Newman [1878] 1909, p. 251), distinguishing it sharply from other movements and systems of that time. Reflecting on the continuity of principles undergirding Christianity, catholicity is noted, but also as containing other principles that have not been developed or defined by the church (ibid., pp. 179-80). Regardless, Newman later remarks in the essay that catholicity has been too long a mark of the church to be an error, affirming that it has involved a long series of developments, something indicative of principles, as well as doctrines, even if the latter see developments earlier and more frequently than the former (ibid., p. 436). This idea will be revisited in more detail below in the analysis of integration and assimilation.

More often in the 'Essay on Development', Newman understands catholicity as part of the church's sacramental constitution as the mystical Body of Christ present throughout the world, and thus as part of the sacramental principle (see Ker 2009, p. 137). By sacramental principle, Newman means "the view which Christianity takes of Matter as susceptible of grace, or as capable of union with a Divine Presence and influence" (Newman [1878] 1909, p. 399). Newman refers to the Incarnation as archetypal with respect to the sacramental principle (ibid., pp. 93-94), given its paradigmatic 'gracing' of nature that was and remains influenced; creation can thus participate in and be transformed by divine grace in a new 
way. Newman's view of catholicity within the sacramental principle can be discerned in the following passage: "From the Sacramental Principle come the Sacraments so called; the unity of the Church, and the Holy See as its type and centre; the authority of Councils; the sanctity of rites; the veneration of holy places, shrines, images, vessels, furniture, and vestments" (ibid., p. 94). For Newman, the church's oneness and presence sacramentally throughout the world were tied together, and its teaching authority-through councils and the pope-were seen as manifestations of the church's catholicity in safeguarding revelation throughout the whole body of the faithful. Therefore, the dogmatic and sacramental principles are tied together in Newman's thought, which sees the very events of salvation history revealing their operation in the concrete life of the developing church.

Even when doctrinal developments appear difficult to reconcile in terms of continuity with past utterances or views of the church, Newman affirms that such elaborations are preserving the underlying principles and thus maintaining the continuity of the faith and Christian system. For example, a third-century synod of the church may have condemned the use of 'homoousios' (i.e., consubstantial) when referring to God's Word in a Sabellian or modalist sense (Cimorelli 2017, p. 102 n. 42), but the fourth-century church could make this philosophical term the standard of orthodoxy given that it was seen as answering the threat posed by Arianism-which directly threatened the principles of dogma and sacramentality by denying full divinity to the Word of God united to humanity. As principles are threatened, activity ensues that ultimately will safeguard them, and doctrinal developments occur. Such developments unearth or focus attention on what may have been previously implicit, and such consciousness can inspire development of the principles themselves. Newman writes, "these principles of Catholic development admit of development themselves, and have in fact developed .... And ... it might be expected that the Catholic principles would be later in development than Catholic doctrines, as lying deeper in the mind, and as being its assumptions rather than its objective professions" (Newman [1845] 2010, p. 368). Newman focuses on how the deeper principle of catholicity, particularly regarding papal supremacy, was itself drawn forth in history, and subsequently developed: "When the Church, then, was thrown upon her own resources, first local disturbances gave exercise to Bishops, and next ecumenical disturbances gave exercise to Popes; and whether communion with the Pope was necessary for Catholicity would not and could not be debated till a suspension of that communion had actually occurred" (Newman [1878] 1909, p. 151). Therefore, while formal assertions of papal primacy are not apparent when reviewing the most ancient of Christian sources, the latent principle of catholicity has remained throughout.

Moreover, this perspective on development, set within a sacramental frame, calls for Christianity, as founded by God the author of reality and truth, to engage with and possibly integrate faithfully whatever appears to be outside of its existing system and life or even challenges its truth claims. He argues that any living idea or system will exhibit development as it is realized in the lives of those committed to it and who live in particular socio-historical contexts (ibid., p. 33ff). Newman writes, "the rulers of the Church from early times were prepared, should the occasion arise, to adopt, or imitate, or sanction the existing rites and customs of the populace, as well as the philosophy of the educated class" (ibid., p. 372). Such was the case with the use of Greek philosophy and 'homoousios' in early Christianity, mentioned above. Section 2 above analyzed catholicity in terms of the church's missionary task in the world, as well as the benefit that potentially accrues to the church as it engages with non-Christians and ideas pertaining to the advancement of humanity. Historical investigations into church history support this view and would sanction this practice, according to Newman, especially when principles have been challenged or are under threat.

At this point, it is worth highlighting the potential of this Newmanian view in terms of Christian creativity in discovering continuity amid development. Newman was well aware of the 'messiness' of history and how that presents a problem for many attempting to see God's presence and providence throughout it (see ibid., p. 312). Consequently, his 'Essay 
on Development' does not shy away from such problems, but offers readers an avenue for discovering continuity despite the inability to predict, in advance, what developments might arise in church history (see ibid., pp. 56, 60ff (at 64), and 354). Newman's theory can thus accommodate cosmological and biological views of emergence in the present: namely, that new phenomena are not reducible to the properties of what came before them (See Delio 2015, pp. 49-53; Vintiadis 2013). Newman's views thus contain great potential for the dialogue between religion and science today, to which we now turn.

\section{Concluding Remarks: Implications for Catholicity in the Twenty-First Century}

One of the strengths of Newman's perspective is the way that it squarely anticipates challenges to the faith and the ability of Christians to use scripture, tradition, and elements of society and culture-including education-to preserve it. Such activity is not merely defensive, and development will occur in order to safeguard the essentials, so to speak. Today, Christians have the benefit of two-thousand years of reflection on catholicity, which has seen much development in terms of the awareness of Christ's church present throughout the world, preaching the gospel to all peoples. In addition, the church has formally reflected on its sacramental and institutional structure and how they relate to the church as the "universal sacrament of salvation" that possesses the full means of grace to facilitate participation in God. But there are significant challenges today to the concept of catholicity. Namely, the very notion of 'the whole' has changed considerably for most people given advancements in science and the understanding of life, of which humanity is a part. Such challenges are opportunities for the development of catholicity today, in order to strengthen it and preserve continuity of the faith. This section will briefly explore how contemporary ecological studies might enhance the church's understanding of catholicity, particularly given what it involves: Christ's presence, missionary activity, and respectful dialogue that benefits the church.

A genuinely sacramental vision emphasizes the ability of the natural world to reflect or indicate the divine source. Jesus the Christ was/is the Incarnation of God's Word, the author of reality that reflects the beauty and wisdom of the Lord, indeed proclaiming the glory of the Lord. Yet, the natural world and its webs of life are currently 'groaning', to use Pope Francis's language (Francis 2015, no. 2), due to the harm inflicted by humanity (see USGCRP 2018, pp. 12-19) which fails to keep in mind the whole on which it depends and with which it is interdependent. The church that would preach Christ throughout the world and make Christ present sacramentally must integrate knowledge about the natural world if it is to remain the "universal sacrament of salvation".

Contemporary ecotheology has thus emerged in response to the ecological crises facing humanity and indeed the whole of the natural world, demonstrating how such respectful dialogue and integration may assist the church today in fulfilling its fundamental tasks, but in a new way. Elizabeth Johnson, in her 2014 book, 'Ask the Beasts: Darwin and the God of Love', investigates Darwin's theory of evolution and its development in the years since it was first introduced. What emerges from this study is the deep interrelatedness of natural lifeforms (see Miller 2020), which have long histories and genealogies (Johnson 2014, p. 98), as well as the implicit capacity for variation and development (ibid., pp. 48-65). Life has become increasingly complex throughout time, and yet more complex lifeforms still rely on the less complex in a multitude of ways: for example, by containing adaptations and developments from earlier ones in their genetic codes, and by relying on other lifeforms for sustenance or even agricultural services in the case of humanity. Variations, or mutations, do not always ensure success of a given species; in fact, the variations may or may not endure depending on the circumstances and local contexts in which they unfold, and the degree to which species collaborate and compete (see ibid., pp. 27, 49ff). Some adaptations ensured success in past ages, but no longer do so as circumstances change. Despite any patterns of increasing complexity, there are organisms that, as a whole, contain properties that together facilitate genuinely novel capabilities that could not have been comprehensively predicted in advance, or might not have emerged if the clock were 
rewound, so to speak, and history redone; this involves the idea of emergence noted above (see ibid., pp. 115-17, 174-80; Francis 2015, nos. 79-83). The human being is one such example, given the drastic increase in language facility and brain power that occurred despite a similar genetic code to other primates (Johnson 2014, pp. 236-41; cf. Francis 2015, no. 81).

The view that emerges from such inquiries into biology and evolution is one of a universe featuring open-ended development rather than rigid control by a divine source, or a creation completed in the distant past. From a Christian perspective, then, the transcendent God-author and sustainer of creation-has established a universe that has relative autonomy and is in some sense emergent (see Johnson 2014, pp. 124-25; Delio 2015, pp. 120-25). With respect to the natural world, the increasing awareness of evolutionary processes, interdependent webs of life, and emergence challenges the notion of humanity as entirely separate or simply above the rest of the creation. It raises an "ethical challenge and ... imperative" (Schillebeeckx 2014a, p. 29), especially given threats to all life posed by accelerating extinction rates and biodiversity collapse (Johnson 2014, pp. 248-53), which have been-since the Industrial Revolution-and remain to this day exacerbated by human development, consumption, and increasing greenhouse gas concentrations that result from them (Miller 2018, pp. 117-32). Pope Francis has called for ecological education and conversion in response to these troubling signs of the times (Francis 2015, no. 202ff), and Johnson has advocated a theological shift from an anthropocentric view of reality and salvation to a theo- and cosmo-centric one (Johnson 2014, pp. 258-69). Such a shift would, in the first place, be a recovery of a truly sacramental worldview prevalent in past ages of Christian life and teaching. In the second place, this shift-incorporating the incredible knowledge of the natural world gained in recent centuries-would require an emphasis on 'deep incarnation,' or the idea that God's Word united with not just human life, but all aspects of that life-down to the very tissues, cells, and atoms-on this planet and that are an integral part of human existence (ibid., pp. 192-99). Deep incarnation would imply deep resurrection and the renewal/redemption of all the world (see ibid., pp. 207-10).

A universe that is not pre-determined is one in which Christians can respond in new ways that are yet faithful to their fundamental principles. This is, in fact, the heart of Newman's view, which (1) is acutely aware of how challenges to the faith often require the engagement of myriad sources within and outside of the church's life, and thus (2) anticipates well the arguments of 'Gaudium et Spes' nos. 44-45 in terms of the church's sacramental presence and engagement with the world. The ongoing commitment of Christians today is what simultaneously preserves and develops their living tradition, including its doctrines and, according to Newman, potentially its principles. In this vein, the sacramental principle implies the genuine goodness of creation and matter that is graced by God. Yet, the natural world exists under dire threat today. The church catholic that would "make disciples of all nations" (Matt. 28:16) must, in fact, "proclaim the gospel to every creature" (Mark 16:15), in view of the redemption of not just persons, but all earthly life that human existence implies and depends upon. This line of thought indicates the potential retrieval of ancient notions such as "recapitulation," set within sweeping sacramental visions and theologies of history, with Irenaeus of Lyons being a prime example (see Cross and Livingstone 1997, s.v. "Recapitulation," p. 1370; Eph. 1:10; Anderson 2010, pp. 21-27). Catholic Christians plumbing the depths of their own tradition todayretrieving perspectives and resources that have been overshadowed to some extent-do so within a context of increased ecological awareness stemming from gains in the natural sciences and interdisciplinary dialogue. Their own dialogue and engagement intending to meet today's challenges will likely yield developments not only in Christian teaching, but also in the understanding of core underlying principles such as catholicity and sacramentality. Newman's theory holds that such developments do not undermine the continuity of the Christian faith, but secure it. What eventually emerges is something new, yet old, which could not be fully predicted in advance.

Funding: This research received no external funding. 
Institutional Review Board Statement: Not applicable.

Informed Consent Statement: Not applicable.

Data Availability Statement: Not applicable.

Conflicts of Interest: The author declares no conflict of interest.

\section{Notes}

1 It should be noted here that the scope of this article will not allow a full treatment of the seven 'notes' or 'tests' that Newman articulates in his 'Essay on Development' that help one to understand authentic development in the life of the church.

2 This is to say that the church's formal dogmatic truths (i.e., dogmas) are distinguished from the dogmatic principle (or principle of dogma) in Newman's thought.

\section{References}

AG (Ad Gentes). 1965. Decree on the Missionary Activity of the Church. The Holy See. Available online: https://www.vatican.va/ archive/hist_councils/ii_vatican_council/documents/vat-ii_decree_19651207_ad-gentes_en.html (accessed on 21 June 2021).

Anderson, William P. 2010. A Journey through Christian Theology with Texts from the First to the Twenty-First Century, 2nd ed. Minneapolis: Fortress Press.

Benedict XVI. 2013. Meeting with the Parish Priests and the Clergy of Rome. The Holy See. Available online: https://www.vatican.va/ content/benedict-xvi/en/speeches/2013/february/documents/hf_ben-xvi_spe_20130214_clero-roma.html (accessed on 21 June 2021).

Catechism of the Catholic Church. 1993. IntraText Editorial Staff, ed. Citta del Vaticano: Libreria Editrice Vaticana. Available online: https:/ / www.vatican.va/archive/ENG0015/_INDEX.HTM (accessed on 21 June 2021).

Cimorelli, Christopher. 2017. John Henry Newman's Theology of History: Historical Consciousness, Theological 'Imaginaries', and the Development of Tradition. Studies in Philosophical Theology 60. Leuven: Peeters.

Cross, Frank Leslie, and Elizabeth A. Livingstone, eds. 1997. Oxford Dictionary of the Christian Church, 3rd ed. Oxford: Oxford University Press.

Delio, Ilia. 2015. Making All Things New: Catholicity, Cosmology, Consciousness. Maryknoll: Orbis Books.

DH (Dignitatis Humanae). 1965. Declaration on Religious Freedom. The Holy See. Available online: https://www.vatican.va/archive/ hist_councils/ii_vatican_council/documents/vat-ii_decl_19651207_dignitatis-humanae_en.html (accessed on 21 June 2021).

Doyle, Dennis M. 2012. The Concept of Inculturation in Roman Catholicism: A Theological Consideration. U.S. Catholic Historian 30: 1-13. [CrossRef]

DV (Dei Verbum). 1965. Dogmatic Constitution on Divine Revelation. The Holy See. Available online: https://www.vatican.va/ archive/hist_councils/ii_vatican_council/documents/vat-ii_const_19651118_dei-verbum_en.html (accessed on 21 June 2021).

Finucane, Daniel. 2011. The People of God: The Church. In Theological Foundations, Alternate Edition. Edited by J. J. Mueller. Winona: Anselm Academic, pp. 101-20.

Francis. 2015. Laudato Si': On Care for Our Common Home. The Holy See. Available online: https://www.vatican.va/content/ francesco/en/encyclicals/documents/papa-francesco_20150524_enciclica-laudato-si.html (accessed on 21 June 2021).

GS (Gaudium et Spes). 1965. Pastoral Constitution on the Church in the Modern World. The Holy See. Available online: https://www. vatican.va/archive/hist_councils/ii_vatican_council/documents/vat-ii_const_19651207_gaudium-et-spes_en.html (accessed on 21 June 2021).

International Theological Commission. 2011. Theology Today: Perspectives, Principles and Criteria. The Holy See. Available online: https: / /www.vatican.va/roman_curia/congregations/cfaith/cti_documents/rc_cti_doc_20111129_teologia-oggi_en. html (accessed on 21 June 2021).

Johnson, Elizabeth A. 2014. Ask the Beasts: Darwin and the God of Love. London: Bloomsbury.

Ker, Ian. 2009. The Church as Communion. In The Cambridge Companion to John Henry Newman. Edited by Ian Ker and Terrence Merrigan. Cambridge: Cambridge University Press, pp. 137-55.

Ker, Ian. 2014. Newman on Vatican II. Oxford: Oxford University Press.

LG (Lumen Gentium). 1964. Dogmatic Constitution on the Church. The Holy See. Available online: https://www.vatican.va/archive/ hist_councils/ii_vatican_council/documents/vat-ii_const_19641121_lumen-gentium_en.html (accessed on 21 June 2021).

Marr, Ryan J. 2018. To Be Perfect Is to Have Changed Often: The Development of John Henry Newman's Ecclesiological Outlook, $1845-1877$. London: Lexington Books/Fortress Academic.

Merrigan, Terrence. 1991. Clear Heads and Holy Hearts: The Religious and Theological Ideal of John Henry Newman. Louvain Theological and Pastoral Monographs 7. Louvain: Peeters Press.

Miller, Richard W. 2018. The Cry of the Earth: The Scientific Background of Laudato si'. In All Creation is Connected: Voices in Response to Pope Francis's Encyclical on Ecology. Edited by Daniel R. DiLeo. Winona: Anselm Academic, pp. 113-34.

Miller, Vincent. 2020. A Cathedral Not Made by Hands: Laudato si' in an Old-Growth Forest. Commonweal Magazine. Available online: https:/ / www.commonwealmagazine.org/ cathedral-not-made-hands (accessed on 20 June 2021). 
NA (Nostra Aetate). 1965. Declaration on the Relation of the Church to Non-Christian Religions. The Holy See. Available online: https: //www.vatican.va/archive/hist_councils/ii_vatican_council/documents/vat-ii_decl_19651028_nostra-aetate_en.html (accessed on 21 June 2021).

Newman, John Henry. 1901. The Via Media of the Anglican Church. London: Longmans, Green, and Co., vol. I. First published 1877. Available online: https:/ / newmanreader.org/works/index.html (accessed on 14 June 2021).

Newman, John Henry. 1908. Apologia Pro Vita Sua: Being a History of His Religious Opinions. London: Longmans, Green, and Co. First published 1865. Available online: https:/ / newmanreader.org/works/apologia65/index.html (accessed on 14 June 2021).

Newman, John Henry. 1908. The Indwelling Spirit. In Parochial and Plain Sermons. London: Longmans, Green, and Co., vol. 2. First published 1835. Available online: https://newmanreader.org/works/parochial/volume2/sermon19.html (accessed on 21 June 2021).

Newman, John Henry. 1909. An Essay on the Development of Christian Doctrine. London: Longmans, Green, and Co. First published 1878. Available online: https: / / digitalcollections.newmanstudies.org/ (accessed on 21 June 2021).

Newman, John Henry. 2004. Discussions and Arguments on Various Subjects. Introduction and Notes by Gerard Tracey and James Tolhurst. Notre Dame: University of Notre Dame Press. First published 1907.

Newman, John Henry. 2010. An Essay on the Development of Christian Doctrine. Cambridge: Cambridge University Press. First published 1845.

Nichols, Aidan. 1990. From Newman to Congar: The Idea of Doctrinal Development from the Victorians to the Second Vatican Council. Edinburgh: T\&T Clark.

Parker, Kenneth L., and C. Michael Shea. 2015. Roman Catholic Theological Receptions of the Essay on Development. In Receptions of Newman. Edited by Frederick D. Aquino and Benjamin J. King. Oxford: Oxford University Press, pp. 30-49.

Paul VI. 1975. Evangelii Nuntiandi. The Holy See. Available online: https:/ /www.vatican.va/content/paul-vi/en/apost_exhortations/ documents/hf_p-vi_exh_19751208_evangelii-nuntiandi.html (accessed on 21 June 2021).

Pereiro, James. 2008. 'Ethos' and the Oxford Movement: At the Hearth of Tractarianism. Oxford: Oxford University Press.

Prickett, Stephen. 1976. Romanticism and Religion: The Tradition of Coleridge and Wordsworth in the Victorian Church. London: Cambridge University Press.

Schillebeeckx, Edward. 2014a. Church: The Human Story of God. Vol. X of the Collected Works of Edward Schillebeeckx. Edited by Ted Mark Schoof and Carl Sterkens. New York: Bloomsbury.

Schillebeeckx, Edward. 2014b. Discontinuities in Christian Dogmas. In Essays: Ongoing Theological Quests. Vol. XI of the Collected Works of Edward Schillebeeckx. Translated by Marcelle Manley. Edited by Ted Mark Schoof and Carl Sterkens. New York: Bloomsbury, pp. 85-109.

Schreiter, Robert J. 2012. Gaudium et Spes: The Church in the World. New Theology Review 25: 39-44.

Thomas, Stephen. 1991. Newman and Heresy: The Anglican Years. Cambridge: Cambridge University Press.

UR (Unitatis Redintegratio). 1964. Decree on Ecumenism. The Holy See. Available online: https://www.vatican.va/archive/hist_ councils/ii_vatican_council/documents/vat-ii_decree_19641121_unitatis-redintegratio_en.html (accessed on 21 June 2021).

USGCRP. 2018. Impacts, Risks, and Adaptation in the United States: Fourth National Climate Assessment, Volume II: Report-in-Brief. Edited by D. R. Reidmiller, C. W. Avery, D. R. Easterling, K. E. Kunkel, K. L. M. Lewis, T. K. Maycock and B. C. Stewart. Washington, DC: U.S. Global Change Research Program, pp. 12-19. Available online: nca2018.globalchange.gov (accessed on 21 June 2021 ).

Vintiadis, Elly. 2013 Emergence. Internet Encyclopedia of Philosophy. Available online: https://iep.utm.edu/emergenc/ (accessed on 6 July 2021). 